\title{
ACUTE TOXICITY OF BUTACHLOR TO RUTILUS RUTILUS CASPICUS AND SANDER LUCIOPERCA IN VIVO CONDITION
}

\author{
Mohammad FOROUHAR VAJARGAH * and Aliakbar HEDAYATI ** \\ * Guilan University, Faculty of Natural Resources, Guilan, Iran, P. O. Box 816, IR-68536-65263, \\ mohammad.forouhar@yahoo.com \\ ** Gorgan University of Agricultural Sciences and Natural Resources, Faculty of Fisheries and \\ Environment, Basij Square, Daneshgah Boulevard, Gorgan, Iran, P. O. Box 219, IR-49316-15581, \\ hedayati@gau.ac.ir
}

DOI: 10.1515/trser-2017-0023

KEYWORDS: agricultural poison, fish, lethal toxicity, Gorgan Province, Iran. ABSTRACT

Herbicides are used to control weeds and are usually targeted to sites that are specific to plants. Butachlor is an herbicide of the acetanilide class, which is widely used in agricultural fields. At the present study, lethal concentration (LC50) of butachlor was calculated for Rutilus rutilus caspicus and Sander lucioperca with a mean weight of $4 \pm 1 \mathrm{~g}$ (mean \pm SD). Our results indicated that LC50 $96 \mathrm{~h}$ butachlor for $R$. rutilus caspicus and S. lucioperca were 0.342 and $0.760 \mathrm{ppm}$ respectively. These findings suggest that butachlor is moderately toxic and moderately irritating for these two species. Clinical symptoms included irregular protrusion of the eyes and irregular swimming.

RESUMEN: Toxicidad aguda in vivo en la pez (Rutilus rutilus caspicus) y la lucioperca (Sander lucioperca) al butacloro.

Los herbicidas se utilizan para controlar el crecimiento de hierba mala y suelen ser dirigidos a los procesos y sitios de destino que son específicos de las plantas. El butacloro es un herbicida de la clase acetanilida que se utiliza comúnmente en campos agrícolas. En el presente estudio se calculó la concentración letal (LC50) de butacloro para especímenes de Rutilus rutilus caspicus y Sander lucioperca cuyo un peso medio fue de $4 \pm 1$ g (media \pm DE). Nuestros resultados fueron que se obtuvo 0.342 y 0.760 ppm de LC50 96 h butacloro en R. rutilus caspicus y S. lucioperca, respectivamente. Estos hallazgos sugieren que el butacloro es moderadamente tóxico y moderadamente irritante para estas dos especies. Se observaron síntomas clínicos incluyendo protrusión irregular de los ojos y natación irregular.

REZUMAT: Toxicitatea acută in vivo a butaclorului la Rutilus rutilus caspicus și Sander lucioperca.

Erbicidele sunt folosite pentru a controla buruienile și sunt de obicei orientate spre procesele și site-urile țintă specifice plantelor. Butaclor este un erbicid din clasa acetanilida, care este utilizat pe scară largă în terenuri agricole. În prezentul studiu, concentrația letală (CL50) de butaclor a fost calculată pentru Rutilus rutilus caspicus și Sander lucioperca cu o greutate medie de $4 \pm 1 \mathrm{~g}$ (valoare medie \pm SD). Rezultatele noastre au indicat că LC50 $96 \mathrm{~h}$ butaclor pentru Rutilus rutilus caspicus și Sander lucioperca sunt 0,342 și 0,760 ppm. Aceste rezultate sugerează ca butaclor este moderat toxic și moderat iritant pentru aceste două specii. $\mathrm{Au}$ fost observate simptome clinice, inclusiv proeminența neregulată a ochilor și înot neregulat. 


\section{INTRODUCTION}

Aquatic ecosystems are environments rich in biodiversity (Paltenea et al., 2008; Pekarik et al., 2009; Lengyel et al., 2012; Ong'oa et al., 2013; Sanguila et al., 2015; Balasaheb et al., 2017) but constantly faced human activities threats. However, these environments are not the target for herbicide; nevertheless some studies sighted the presence of herbicides and their metabolites in surface water (Mansingh and Wilson, 1995; Tsuda et al., 1996). Herbicides are the most prevalent environmental pollutants worldwide (Khoshnood, 2017). Herbicides are used to control weeds and are targeted to sites specific to plants, exceptions are uncouples of oxidative phosphorylation and herbicides that interfere with cell division (Solomon et al., 2013).

Butachlor is an herbicide of the acetanilide class and is used as a selective preemergent herbicide with $\mathrm{C}_{17} \mathrm{H}_{26} \mathrm{ClNO}_{2}$ molecular formula. Butachlor is one of the most widely used chloro-acetanilide herbicide for the control of annual grasses in rice fields and many broadleaf weeds (Nwani et al., 2013). The herbicide has contaminated river water via the effluents from rice paddy fields. Fish accumulate these chemicals by directly exposure to the chemicals present in water or indirectly through the ecosystem food chain (Ateeq et al., 2002). Butachlor is persistent in agricultural soil and water systems, posing a potential threat to the agro-ecosystem and human health (Debnath et al., 2002; Vajargah et al., 2013).

Rutilus rutilus caspicus (Caspian roach) is one of the most valuable inhabitants of the Caspian Sea, however, the Caspian roach population has recently declined in the Caspian Sea because of overfishing, a degraded habitat, and pollution (Hoseini and Nodeh, 2012). Sander lucioperca (Pikeperch) is found in freshwater and brackish water, which is a semi-anadromous, cool-water species in the Caspian Watershed (Ural, Volga, Kura, and Sefid Roud rivers) and in the basins of the Black, Azov, Aral, and Baltic Seas (Abdolmalaki and Psuty, 2007). As a predator and commercially valuable species, pikeperch constitute an important component of the Caspian ichthyofauna, both ecologically and commercially (Abdolmalaki and Psuty, 2007).

The contamination of aquatic ecosystems by butachlor has gained increased attention and several studies have been conducted on acute toxicity and the destructive effect of this herbicide in some fish (Tilak et al., 2007; Geng et al., 2010; Chang et al., 2013; Nwani et al., 2013; Vajargah et al., 2014) but data on acute toxicity of this herbicide on Pikeperch and Caspian roach is scarce. Despite the large use of butachlor in agriculture and the potential ecotoxicological impact, there is a scarcity of data on its effects on many Caspian Basin fish species like Caspian roach or Pikeperch. Sensitivity of various fish species is different on toxic substances, so toxicology tests are needed for different fish. For this purpose, LC50 $96 \mathrm{~h}$ is required of any ecotoxicology studies.

\section{MATERIAL AND METHODS}

231 live specimens of Caspian roach and Pikeperch were obtained from hatchery and ponds in Gorgan Province. Samples weighted $4 \pm 1 \mathrm{~g}$ acclimatized in $60 \times 55 \times 30 \mathrm{~cm}$ aquarium for 10 days. In order to measure biological capability and determine survival, fish were kept in natural and toxin-free environment to determine natural mortality. Physical and chemical parameters of water are represented in table 1 . The fish were fed twice daily with Biomar feed at $2 \%$ body weight before the test, but feeding was stopped $24 \mathrm{~h}$ prior to and throughout the test. The faecal matter and other waste materials were siphoned off daily to reduce ammonia content in water. Commercial butachlor (Machete, EC 60\%) was purchased from Exir Keshavarzi Co, Iran. All Experiments were performed with 16-hours of light and eight hours of darkness. Static acute toxicity test was performed following guideline the OECD standard method (OECD, 1989). 10 treated aquariums with concentration ranges $0.11,0.22,0.33,1$, 1.66, 2.33, 3.33, 6.66, 13.33, 16.66 and control groups (no toxic concentration) were 
performed. Mortality rates were recorded after 24, 48, 72 and 92 hours and dead fish were quickly removed from the aquarium. The nominal concentration of toxin causing mortality (LC1،LC10 ، LC30 ‘LC50 ‘LC70 ‘LC90 and LC99) within 24, 48, 72 and 92 hours for each toxin was calculated separately. LC50 values for 24, 48, 72 and 96 h exposures were computed on the basis of probit analysis version 16/0.

This work was approved by the ethical committee of GAU University. To minimize suffering of the fish, all animals were exposed to clove essence, and a low dose of anesthesia; hypothermia prior to euthanasia and eventually spinal cord dislocation for euthanasia.

Table 1: Physico-chemical properties of the test water.

\begin{tabular}{|l|c|c|c|c|}
\hline Physico-chemical indices & $24 \mathrm{~h}$ & $48 \mathrm{~h}$ & $72 \mathrm{~h}$ & $96 \mathrm{~h}$ \\
\hline $\mathrm{pH}$ & 8.22 & 8.28 & 8.25 & 8.30 \\
\hline BOD & $69 \%$ & $68 \%$ & $67 \%$ & $68 \%$ \\
\hline Temperature $\left(\mathrm{C}^{\circ}\right)$ & 17.9 & 17.8 & 17.9 & 17.7 \\
\hline $\left.\begin{array}{l}\text { Total hardness } \\
(\mathrm{MgCaCo}\end{array}\right)$ & 210 & 210 & 210 & 210 \\
\hline
\end{tabular}

\section{RESULTS}

No mortality was observed during acclimation (Tabs. 2 and 3). Result showed that within a $96 \mathrm{~h}$ test, the LC50 value declined with increasing toxin concentration and duration of exposure. This shows that an LC50 value in the first 24 hours of the experiment was always higher than LC50 $96 \mathrm{~h}$. According to the results LC50 $96 \mathrm{~h}$ Butachlor for Rutilus rutilus caspicus and Sander lucioperca were obtained 0.342 and $0.760 \mathrm{ppm}$ respectively. Fish had a $100 \%$ mortality rate only hour after exposure in 13.33 and $16.66 \mathrm{ppm}$ concentration. The nominal concentration of toxin causing mortality (LC1،LC10 ، LC30 ‘LC50 ‘LC70 ،LC90 and LC99) within 24, 48, 72 and 92 hours for each toxin was calculated (Tab. 4). It was significantly different between experiment fish, that in all steps, mortality was higher for Caspian roach during exposure to butachlor, Caspian roach is more sensitive in comparison with Pikeperch.

Table 2: Mortality rate in acute toxicity $\left(\mathrm{LC}_{50} 96 \mathrm{~h}\right)$ rate for Caspian roach $(\mathrm{n}=21$ each treatment).

\begin{tabular}{|c|c|c|c|c|}
\hline Concentration (mg/l) & $24 \mathrm{~h}$ & $48 \mathrm{~h}$ & $72 \mathrm{~h}$ & $96 \mathrm{~h}$ \\
\hline Control & 0 & 0 & 0 & 0 \\
\hline 0.11 & 0 & 0 & 3 & 5 \\
\hline 0.22 & 0 & 3 & 4 & 7 \\
\hline 0.33 & 2 & 4 & 11 & 17 \\
\hline 1 & 2 & 3 & 15 & 19 \\
\hline 1.66 & 5 & 9 & 19 & 21 \\
\hline 2.33 & 4 & 9 & 21 & 21 \\
\hline 3.33 & 4 & 21 & 21 & 21 \\
\hline 6.66 & 15 & 21 & 21 & 21 \\
\hline 13.33 & 21 & 21 & 21 & 21 \\
\hline 16.66 & 21 & 21 & 21 & 21 \\
\hline
\end{tabular}


Table 3: Mortality rate in acute toxicity $\left(\mathrm{LC}_{50} 96 \mathrm{~h}\right)$ rate for Pikeperch $(\mathrm{n}=21$ each treatment).

\begin{tabular}{|c|c|c|c|c|}
\hline Concentration (mg/l) & $24 \mathrm{~h}$ & $48 \mathrm{~h}$ & $72 \mathrm{~h}$ & $96 \mathrm{~h}$ \\
\hline Control & 0 & 0 & 0 & 0 \\
\hline 0.11 & 0 & 0 & 2 & 4 \\
\hline 0.22 & 0 & 0 & 3 & 7 \\
\hline 0.33 & 1 & 3 & 9 & 13 \\
\hline 1 & 2 & 4 & 10 & 13 \\
\hline 1.66 & 3 & 6 & 11 & 17 \\
\hline 2.33 & 3 & 11 & 15 & 19 \\
\hline 3.33 & 6 & 15 & 21 & 21 \\
\hline 6.66 & 11 & 19 & 21 & 21 \\
\hline 13.33 & 21 & 21 & 21 & 21 \\
\hline 16.66 & 21 & 21 & 21 & 21 \\
\hline
\end{tabular}

Table 4: Lethal concentration of butachlor (mg/l) (95\% confidence intervals) depending on exposure time for Caspian roach and Pikeperch.

\begin{tabular}{|c|c|c|c|c|c|c|}
\hline \multirow[t]{3}{*}{ LC } & \multirow{2}{*}{\multicolumn{2}{|c|}{$\begin{array}{c}96 \mathrm{~h} \\
\text { Exposure time }\end{array}$}} & \multicolumn{4}{|c|}{ 95\% confidence intervals } \\
\hline & & & Cas & oach & & \\
\hline & $\begin{array}{c}\text { Caspian } \\
\text { roach }\end{array}$ & Pikeperch & & $\begin{array}{l}\text { Caspian } \\
\text { roach }\end{array}$ & Pikeperch & \\
\hline $\mathrm{LC}_{10}$ & - & - & $\mathrm{LC}_{10}$ & - & - & $\mathrm{LC}_{10}$ \\
\hline $\mathrm{LC}_{20}$ & 0.052 & - & $\mathrm{LC}_{20}$ & 0.052 & - & $\mathrm{LC}_{20}$ \\
\hline $\mathrm{LC}_{30}$ & 0.162 & 0.247 & $\mathrm{LC}_{30}$ & 0.162 & 0.247 & $\mathrm{LC}_{30}$ \\
\hline $\mathrm{LC}_{40}$ & 0.255 & 0.512 & $\mathrm{LC}_{40}$ & 0.255 & 0.512 & $\mathrm{LC}_{40}$ \\
\hline $\mathrm{LC}_{50}$ & 0.342 & 0.760 & $\mathrm{LC}_{50}$ & 0.342 & 0.760 & $\mathrm{LC}_{50}$ \\
\hline $\mathrm{LC}_{60}$ & 0.430 & 1.008 & $\mathrm{LC}_{60}$ & 0.430 & 1.008 & $\mathrm{LC}_{60}$ \\
\hline $\mathrm{LC}_{70}$ & 0.523 & 1.273 & $\mathrm{LC}_{70}$ & 0.523 & 1.273 & $\mathrm{LC}_{70}$ \\
\hline $\mathrm{LC}_{80}$ & 0.632 & 1.584 & $\mathrm{LC}_{80}$ & 0.632 & 1.584 & $\mathrm{LC}_{80}$ \\
\hline $\mathrm{LC}_{90}$ & 0.784 & 2.015 & $\mathrm{LC}_{90}$ & 0.784 & 2.015 & $\mathrm{LC}_{90}$ \\
\hline $\mathrm{LC}_{95}$ & 0.909 & 2.370 & $\mathrm{LC}_{95}$ & 0.909 & 2.370 & $\mathrm{LC}_{95}$ \\
\hline
\end{tabular}

\section{DISCUSSION}

Acute and chronic toxicity tests are widely used to evaluate the toxicity of chemicals on non-target organisms (Yalsuyi and Vajargah, 2017). Exposure time is one of the effective factors in toxic ratios (Vajargah and Hedayati, 2014). When fish are exposed to a constant concentration of the toxin, fish tolerance is diminished over time and the toxin has a greater effect (Hedayati et al., 2014). However, when the toxin accumulates in fish tissue it increases the adverse effects on the body and causes a decrease in $\mathrm{LC}_{50} 96 \mathrm{~h}$. Overall $\mathrm{LC}_{50}$ for butachlor in Caspian roach and Pikeperch showed a decreasing trend over 96 hours and in listed physicochemical conditions. Result of $\mathrm{LC}_{50} 96 \mathrm{~h}$ for toxin showed that the rate of $\mathrm{LC}_{50}$ decreases with increasing toxin concentration and duration of exposure. The results of the acute toxicity of diazinon and Deltamethrin on Cyprinus carpio (common carp) concedes shows decreasing trend in $\mathrm{LC}_{50} 96 \mathrm{~h}$ (Svoboda et al., 2001, 2003). 
Herbicides can influence aquatic organisms directly and indirectly. Indirect effects are mediated by herbicide-induced changes in food webs or in the physical environment. Indirect effects can only occur if direct effects occur first and would be mediated by the killing of plants by herbicides (Solomon et al., 2013). Results are limited on acute toxicity of butachlor in fish. The influence of butachlor on fish toxicity was evident. Chang et al. (2013) studied the effects of butachlor on reproduction and hormone levels in adult zebra fish (Danio rerio). They declared that butachlor adversely affected the normal reproductive success of zebra fish and disrupted the thyroid and sex steroid endocrine systems. Ateeq et al. (2002, 2006) stated that butachlor causes anisochromasia and anisocytosis of erythrocytes in Clarias batrachus. They reported that this herbicide is genotoxic and cytotoxic and is able to induce apoptosis both at molecular as well as cytological level. Lasheidani et al. (2008) reported that butachlor has adverse effect on density and volume of Caspian Kutum Rutilus frisii kutum. They stated that the number of abnormal sperm increased by $28.6 \pm 1.92 \%$ in fish exposed to high butachlor toxicity ( $75 \%$ of its $\mathrm{LC}_{50}$ value).

Previous studies demonstrated $\mathrm{LC}_{50}$ values of butachlor for Heteropneustus fossilis (Ateeq et al., 2006) and Channa punctatus (Tilak et al., 2007) $2.34 \mathrm{ppm}$ and $247.46 \mathrm{ppb}$, respectively. Also Geng et al. (2005) determined the $\mathrm{LC}_{50} 96 \mathrm{~h}$ values of butachlor in Rana japonica $1.40 \mathrm{mg} / \mathrm{l}$ while Gobic and Gunasekaran (2010) obtained 96 h LC $_{50}$ of $0.515 \mathrm{mg} / \mathrm{l}$ for Eisenia fietida.

Dissolved oxygen, $\mathrm{pH}$, size and age, type of species, water quality, concentration and formulation of test chemicals are the major factors in affecting toxicity of chemicals in aquatic organisms (Nwani et al., 2010; Vajargah et al., 2013). The safe level obtained for butachlor in the present study varied from 0 to $0.157 \mathrm{mg} / \mathrm{l}$ concentration for Rutilus rutilus caspicus and Sander lucioperca in 68\% BOD, pH 8.28, $17 \pm 1^{\circ} \mathrm{C}$ temperature and $210 \mathrm{ppm}$ hardness. However these values are determined in vivo condition.

Herbicides are rapidly absorbed in fish gills which cause respiratory limitations (Masud and Singh, 2013). Fish that were exposed to butachlor had respiratory disorders which quickly opened and closed their gill cover. Fish were anxious, had a harmonic breathing and unusual semi-circular swimming. These findings coincide with studied acute toxicity of butachlor in other fish species, such as Tilapia zillii (Nwani et al., 2013) and Oreochromis niloticus (Bekeh et al., 2011).

According to the results and Toxicity category rating inhalation $\mathrm{LC}_{50}$, butachlor for Rutilus rutilus caspicus and Sander lucioperca are lying in toxicity category II: is Moderately toxic and Moderately irritating (Toxicity Category, 2009). Dou to the vicinity of these two species location to farmland and orchards, further studies should be conducted on acceptable level of this herbicide and the usage must be restricted to avoid the severe risk associated with the use of the pesticide.

\section{CONCLUSIONS}

Few surveys have focused on the effects of butachlor on mortalities indices of various fish species, the current investigation examined $\mathrm{LC}_{50}$ of this herbicide on Caspian roach and Pikeperch. Since the species is edible, infections in turn affect human health. Furthermore, the results show that butachlor is too poisonous for these edible fishes and also Caspian roach is more sensitive than pikeperch. 


\section{ACKNOWLEDGEMENTS}

The authors would like to thank Aquaculture Research Center of Fazli Barabadi and Gorgan University of Agricultural Science and Natural Resources, for providing the necessary facilities. 


\section{REFERENCES}

1. Abdolmalaki S. and Psuty I., 2007 - The effects of stock enhancement of pikeperch (Sander lucioperca) in Iranian coastal waters of the Caspian Sea, ICES Journal of Marine Science, 64, 973-980.

2. Ateeq B., Farah M. A., Ali M. N. and Ahmad W., 2002 - Induction of micronuclei and erythrocyte alterations in the catfish Clarias batrachus by 2,4-dichlorophenoxyacetic acid and butachlor, Mutation Research, 518, 135-144.

3. Ateeq B., Farah M. and Ahmad W., 2006 - Evidence of apoptotic effects of 2,4-Dand butachlor on walking catfish Clarias batrachus by transmission electron microscopy and DNA degradation studies, Life Scince, 78, 977-986.

4. Balasaheb K., Ashok B., Ashok J. and Rahul K., 2017 - Present status of intertidal biodiversity in and around Mumbai (West coast of India), Transylvanian Review of Systematical and Ecological Research, 19.1, The Wetlands Diversity, 61-70.

5. Bekeh A. F., Ndome C. B. and Bayin P. R. B., 2011 - Some hematological changes in Oreochromis niloticus juveniles exposed to butachlor, Journal of Agricultural and Food Technology, 1, 6, 73-80.

6. Chang J., Liu S., Zhou S., Wang M. and Zhu G., 2013 - Effects of butachlor on reproduction and hormone levels in adult zebrafish (Danio rerio), Experimental and Toxicologic Pathology, 65, 205-209.

7. Debnath A., Das A. and Mukherjee D., 2002 - Persistence and effect of butachlor and basalin on the activities of phosphate solubilizing microorganisms in wetland rice soil, Bulletin of Environmental Contamination and Toxicology, 68, 766-70.

8. Geng B. R., Yao D., Huang H., Xue Q., Lian Y. and Zheng Z., 2005 - Acute toxicities and effects of dichlorovos and butachlor to Rana japonica tadpoles and its growth, Herpetol Sinica, 10, 127-132.

9. Geng B., Lin L., Zhang Q. and Zhung B., 2010 - Genotoxicity of the pesticide dichlorvos and herbicide butachlor on Rana zhenhaiensis tadpoles, Asian Herpatology Research, 1, 2, 118-122.

10. Gobic M. and Gunasekaran P., 2010 - Effects of butachlor herbicide on earthworm Eisenia fetida - its histological perspicuity, Applied and Environmental Soil Science, DOI:10.1155/2010/850758, 1-4.

11. Hedayati A., Vajargah F. M., Yalsuyi M. A. Abarghoei S. and Haji A. M., 2014 - Acute toxicity test of pesticide abamectin on common carp, Journal of Coastal Life Medicine, 2, 11, 841-844.

12. Lasheidani M., Balouchi S. N., Keyvan A., Jamili S. and Falakru K., 2008 - Effect of butachlor on density, volume and number of abnormal sperms in caspian kutum (Rutilus Frisii Kutum). Research Journal of Environmental Sciences, 2, 474-482.

13. Lengyel E., Oprean L., Tița O., Iancu R. and Iancu M., 2012 - Biodiversity of the microorganisms existing in the salt lakes at Ocna Sibiului (Romania) and Chott El Jerid (Tunisia), Transylvanian Review of Systematical and Ecological Research, 14. The Wetlands Diversity, 25-32.

14. Nwani C. D., Lakra W. S., Nagpure N. S., Kumar R., Kushwaha B. and Srivastava S. K., 2010 - Mutagenic and genotoxic effects of Carbosulfan in fresh water air-breathing fish Channa punctatus (Bloch) using micronucleus assay and alkaline single-cell gel electrophoresis, Food and Chemical Toxicology, 48, 202-208.

15. Nwani C. D., Ama U. I., Okoh F., Oji U. O., Ogbonyealu R. C., Ibiam A. A. and Udu-Ibiam O., 2013 - Acute toxicity of the chloroacetanilide herbicide butachlor and its effects on the behavior of the freshwater fish Tiliapia zillii, African Journal of Biotechnology, 12, 5, 499-503

16. Ong'oa D. O., Ng'endo R. N., Muya S. M, Nyoike M. M., Malomz P. K. and Osiemo Z. L., 2013 - Diversity and abundance patterns of amphibians in rehabilitated quarries of Bamburi near Mombasa (Kenya), Transylvanian Review of Systematical and Ecological Research, 15.1, The Wetlands Diversity, 61-72. 
17. Paltenea E., Viforeanu A., Bulgaru C. and Jecu E., 2008 - Swamps biodiversity of the White Nile (Sudan), Transylvanian Review of Systematical and Ecological Research, 6, The Wetlands Diversity, 81-86.

18. Pekárik L., Čejka T., Čiamporová-Zatovičová Z., Darolová A., Illéšová D., Illyová M., Pastuchová Z., Gatial E. and Čiampor Fedor, 2009 - Multidisciplinary evaluation of the function and importance of the small water reservoirs: the biodiversity aspect, Transylvanian Review of Systematical and Ecological Research, 8, The Wetlands Diversity, 105-112.

19. Sanguila M. M. and Hansel C., 2015 - Compliance with ichthyofaunal diversity conservation measures in lake Lanao, Lanao del Sur Province (Philippines), Transylvanian Review of Systematical and Ecological Research, 17.2, The Wetlands Diversity, 155-168.

20. Solomon K., Dalhoff K., Volz D. and Van Der Kraak G., 2013 - Effects of Herbicides on Fish, Fish Physiology, 33, 369-403.

21. Svoboda M., Luscova V., Drastichova J. and Ilabek V., 2001 - The effect of diazinon on haematological indices of common carp (Cyprinus carpio), Acta Veterinaria Brno, 10, 457-465.

22. Svoboda Z., Luscova V., Drastichova J., Svoboda M. and Zlabek V., 2003 - Effect of deltamethrin on haematological indices of common carp (Cyprinus carpio), Acta Veterinaria Brno, 72, 79-85.

23. Tilak K. S., Veeraiah K., Thathaji B. and Butchiram M. S., 2007 - Toxicity studies of butachlor to the freshwater fish Channa punctata (Bloch), Journal of Environmental Biology, 28, 2, 485-487.

24. Toxicity Category, 2009 - Code of Federal Regulations, Office of the Federal Register, Retrieved 2009-04-30.

25. Tsuda T., Inoue T., Kojima M. and Aoki S., 1996 - Pesticides in water and fish from rivers flowing into Lake Biva, Bulletin of Environmental Contamination and Toxicology, 57, 442-449.

26. Vajargah F. M. and Hedayati A., 2014 - Acute toxicity of trichlorofon on four viviparous fish (Cyprinodontiformes: Poecilidae), Journal of Coastal Life Medicine, 2, 7, 511-514.

27. Vajargah M. F., Hossaini S. A., Niazie E. H., Hedayati A. and Vesaghi M. J., 2013 - Acute toxicity of two pesticides Diazinon and Deltamethrin on Tench (Tinca tinca) larvae and fingerling, International Journal of Aquatic Biology, 1, 3, 138-42.

28. Vajargah M. F., Hedayati A., Yalsuyi A. M., Abarghoei S., Gerami M. H. and Farsani H. G., 2014 - Acute toxicity of Butachlor to Caspian Kutum (Rutilus frisii Kutum Kamensky, 1991), Journal of Environmental Treatment Techniques, 2, 4, 155-157.

29. Yalsuyi A. M. and Vajargah M. F., 2017 - Acute Toxicity of Silver Nanoparticles in Roach (Rutilus rutilus) and Goldfish (Carassius auratus), Journal of Environmental Treatment Techniques, 5, 1, 1-4. 